\title{
THE EMERGENCE OF A NEW RELIGIOUS TRAVEL SEGMENT: UMRAH DO IT YOURSELF TRAVELLERS (DIY)
}

\author{
Rusli Siti' ATIKAH* \\ Sunway University, School of Hospitality and Service Management, Bandar Sunway, 47500 Selangor, Malaysia; \\ UiTM Cawangan Selangor Kampus Puncak Alam Bandar Puncak Alam, 42300 Puncak Alam, e-mail: atikahr@sunway.edu.my
}

\section{Ai Ling TAN}

Sunway University, School of Hospitality and Service Management, Bandar Sunway, Malaysia, e-mail: ailingt @ sunway.edu.my

Alexander TRUPP

Sunway University, School of Hospitality and Service Management, Bandar Sunway, Malaysia, e-mail: atrupp@ sunway.edu.my

Ka Leong CHONG

Sunway University, School of Hospitality and Service Management, Bandar Sunway, Malaysia, e-mail: danielc@sunway.edu.my

\author{
Abdul Gani ARNI \\ UiTM Cawangan Selangor Kampus Puncak Alam Bandar Puncak Alam, Puncak Alam, Malaysia, e-mail: arni@uitm.edu.my
}

\author{
Vijaya Malar ARUMUGAM
}

Sunway University, School of Hospitality and Service Management, Bandar Sunway, Malaysia, e-mail: vijayam@sunway.edu.my

\begin{abstract}
Citation: Atikah, R.S., Tan, A.L., Trupp, A., Chong, K.L., Arni, A.G., \& Arumugam, V.M. (2022). THE EMERGENCE OF A NEW RELIGIOUS TRAVEL SEGMENT: UMRAH DO IT YOURSELF TRAVELLERS (DIY). GeoJournal of Tourism and Geosites, 40(1), 37-48. https://doi.org/10.30892/gtg.40104-800
\end{abstract}

\begin{abstract}
This research examines the rise of a new religious travel segment - the Umrah Do It Yourself (DIY) travellers. While Hajj is the fifth pillar of Islam, Umrah is a minor Muslim pilgrimage that can be undertaken at any time of the year, while still playing a crucial role in the completion of Hajj rituals. In the past, Umrah was managed by an authorised travel agent, who makes all the necessary pilgrimage preparations, from flights to trip itineraries. Recent years have seen an upsurge in travellers who prefer not to utilise the services of such agencies, but instead, to make their own arrangements. The decision by the Saudi Arabian government to launch a Tourist e-Visa in September 2019 has opened a window of opportunity for the legalization of Umrah DIY journeys. The objectives of this study are (i) to explore the travel motives that contribute to the success of the Umrah DIY, and (ii) to explore the factors that support and facilitate the decision for the Umrah DIY. The data were obtained via 20 semi-structured interviews with Umrah DIY travellers. The findings show that flexibility, spirituality, and budget have a crucial impact on travel motivation. Additionally, the findings suggest that information sources, travel quality, companionship/new friendship, and familiarity facilitate the choice of Umrah DIY travel. This research contributes to the growing scholarship on the Muslim travel market beyond Hajj and to studies on independent religious travel. Findings provide an opportunity for suppliers and industry participants to understand the travel motives of this new segment as a basis for producing relevant religious tourism products and services.
\end{abstract}

Key words: Umrah, Do-it-yourself (DIY), e-Visa, travel motives, religion, Muslim travel

\section{INTRODUCTION}

Religious tourism is broadly defined as travel activities that are related to religious purposes, including visits to holy and sacred places, such as churches, temples or monasteries, to perform pilgrimages or attend events and festivals of religious significance (Kim et al., 2020; Pintér, 2014). Within the scope of religious travel, Islamic tourism and pilgrimages have developed into one of the largest tourist segments globally. However, its academic conceptualisation and exploration from a Muslim perspective have only just begun to grow in recent decades (Eid and Gohary, 2015; Kim, 2020; Luz, 2020).

Existing research on Muslim pilgrimages is focused more on Hajj (Kusumaningtyas, 2019; Almuhrzi and Alsawafi, 2017; Raj and Bozonelos, 2015) rather than on the Umrah. Hajj is only performed once a year in the month of Dhul-Hijjah, and pilgrims must wait for a quota vacancy. While Hajj is the fifth pillar of Islam and has defined rituals from a temporal and practical standpoint, Umrah is voluntary and can be performed at any time, except on Hajj days, and maintains the practice of rituals in much the same way. In Islam, religious and spiritual journeys can be divided into three types: Hajj, Umrah, and Ziyara (Hassan et al., 2015; Haq and Wong, 2010; Timothy and Olsen, 2006). While the Umrah is part of the pilgrimage to Mecca, it is a minor pilgrimage that Muslims can undertake at any time of the year (Heidari et al., 2018), and represents a major form of travel for Muslims worldwide. It can be completed more than once (Hassan et al., 2015), and can be repeated, based on a person's physical and financial capabilities.

\footnotetext{
* Corresponding author
} 
Both the Hajj and Umrah travels have largely been organised in a tightly structured manner in the form of packaged group tours (Haq and Jackson, 2009). According to Hassan et al. (2016), Umrah package travellers are individuals who purchase products (Umrah travel packages) from local tour operators and travel agents for religious and spiritual motives, which typically include lodging, transportation, an itinerary, and food. However, it has been observed recently that there is a trend towards more independent and Do-it-yourself (DIY) Umrah travels (Almuhrzi and Alsawafi, 2017), as evidenced by the DIY Umrah Facebook forum in Indonesia wuth 10,000 members. In this forum, information related to DIY Umrah is shared among members (Lailatul and Melinda, 2018; Fakhruddin and Ubaidillah, 2021). For DIY activities, individuals create, change, or produce something independently (Wolf and McQuitty, 2011). Beyond any other forms of 'creation', DIY projects typically require a great deal of innovation, designing, knowledge, skills, and time.

Fakhruddin and Ubaidillah (2021) noted that for most people, the expenses for Umrah are still extremely high, and with an alternative to a regulated visit to the Holy Land via DIY travel, the cost is seen as a viable. When people perform Umrah independently, they can also invite a few friends along or join other Umrah backpacking groups, which is beneficial for newcomers. This way of travel can also reduce the overall costs, e.g., through the sharing of accommodation or transport. Moreover, Wang et al. (2014) suggested that the advent of technology has facilitated further opportunities for DIY Umrah travellers, where online platforms and applications offer travellers a chance to participate in the sharing of travel journeys, and they are given instant access to the experience. Furthermore, Umrah and Hajj virtual simulations enable DIY travellers to learn about cultures, places, and people online without the help of professionals (Ryoko, 2012). Understanding the motivations for visiting religious places has significant implications for the marketing of religious tourism (Almuhrzi and Alsawafi, 2017).

For travel and destination marketers, understanding why and how people travel is critical for developing appropriate marketing strategies. As stated earlier, much of the literature of religious travel in Islam has focussed on the Hajj with little attention to Umrah and particularly to the DIY aspects of Umrah travel. Existing research on Umrah DIY travel is scarce (Lailatul and Melinda, 2018; Fakhruddin and Ubaidillah, 2021). As the numbers of travellers who want to experience deeper spiritual connection in the religious travel without a rigid tour itinerary increase, it is timely to investigate DIY Umrah travel as a new religious travel segment. This is one of the first studies to assess the emerging phenomenon of fully independent and self-arranged travel in the context of Islamic pilgrimages by addressing the following research objectives: firstly, to explore the motivational factors for DIY Umrah travel among Muslim pilgrims; and secondly, to examine the factors and conditions that support and facilitate the selection of DIY Umrah. The findings will contribute to the growing body of knowledge on Islamic travel and lead to a better understanding of a new and emerging type of DIY Umrah travellers who prefer to develop their own itineraries rather than follow a pre-set travel protocol. This research was based on a qualitative inquiry involving semi-structured interviews with 20 participants to examine a concept that was coined recently for religious travel. Following this introductory section, the literature review, methodology and discussion on the findings will be presented.

\section{LITERATURE REVIEW}

The literature review is organised into three bodies of scholarship which inform this study: 1) Islamic Tourism and Pilgrimage Travel, 2) Umrah Travel, and 3) DIY Travellers. This funnel approach to structuring the existing research begins with scoping background literature related to religious tourism as a general topic area and progresses to discussing literature more relevant to the specific subtype of religious and independent travel. Furthermore, the theoretical underpinning will be presented to guide the conceptual foundations of this study.

\section{Islamic Tourism and Pilgrimage Travel}

Religious tourism has been investigated from a broad range of contexts, but for this study, it was most relevant to consider the perspectives on pilgrimage tourism and Islamic tourism. Islam, with over 1.9 billion followers in 2020 , represents the second largest belief system worldwide (Pew Research Centre, 2021). Di Giovine and Choe (2019) mentioned that a pilgrimage is one of the earliest forms of human travel and a key foundation of contemporary tourism. The writers explained that although a pilgrimage may be done individually, it is most often organised in groups at specific periods of the year. Recent research shows that Islam is the most frequently researched creed, and Islamic tourism is the most studied form of religious travel (Kim et al., 2020). This is remarkable since scholarly interest in Islamic tourism has only just been growing in recent decades (Luz, 2020). Existing studies have examined Muslim tourist satisfaction (Battour et al., 2011), Islamic hospitality (Stephenson, 2014); halal tourism (Rasul, 2019), Islamic brand equity (Shafaei, 2017), the attributes of Muslim destinations (Cuesta-Valino et al., 2020), and the perceived values of Muslim tourists (Eid and Gihary, 2015).

Pilgrimages, whether religious or secular, are gaining popularity across the world. The Hajj and Umrah are forms of pilgrimages that Muslims all over the globe are obligated to perform to bring good fortune (Almuhrzi and Alsawafi, 2017). In this globalised era, it is difficult to avoid the sense that at most pilgrimage sites, the profane effects of tourism are just as prominent, if not more so, than the religious. The pilgrimage environment is characterised by religious congregations, where tourists engage in communal experiences that reflect themselves and their faith. Therefore, the ideal experience, where tourists feel a sense of escapism from the pressures of everyday life, is a product of their ability to project, develop, and ratify their self-concept (Lochrie et al., 2019). In Islam, pilgrimage tourism refers to religious travel to Mecca, such as the Hajj and Umrah pilgrimages, which include visits to three mosques: the al-Masjid al-Haram, the Messenger Mosque, and the Al-Aqsa Mosque. In Islam, travel must be "purposeful," and Muslims are encouraged to travel for religious purposes (Almuhrzi and Alsawafi, 2017). Whilst past research on Muslim pilgrimages and religious travels largely focused on the Hajj, this study followed recent calls to explore Muslim perspectives and religious travels beyond the Hajj (Almuhrzi and Alsawafi, 2017; Luz, 2020). One important reason to explore Umrah travel is that it is one of the largest 
examples of religious pilgrimages today. As Muslims are called to perform their religious obligations, religious tourism and pilgrimages have become increasingly popular, and the demand for Umrah among Malaysians is on the rise (Othman et al., 2021). In 2019, 19 million pilgrims performed Umrah, including almost 7.5 million pilgrims from abroad (Gornall, 2020).

Almuhrzi and Alsawafi (2017) discovered that attaining inner harmony, integrating and seeking opportunities to grow in spirituality, engaging with family and friends about the meaning of life and so on are the motivations for Umrah travel among Oman travellers. Furthermore, a study conducted by Wu and Mursid (2020) on Indonesian Muslim Umrah travellers to Makkah found that quality, price, emotions, social connections and physical and non-physical Islamic attributes are the values that lead to participation in Umrah. Although the results from both studies are inconsistent, they show that the participation of Umrah travellers promotes both hedonic and emotional values, and that there are significant variations between senior and young travellers, where senior travellers see the educational purposes and feelings of national identity related to sacred sites as important, while these are less motivating for young travellers (Irimias et al., 2016). Often, Muslim pilgrims plan and eagerly anticipate performing both Umrah and Hajj, and are willing, in particular, to use their savings and incur expenses (Nurul'Ain and Khairul Faezi, 2019). As a result, senior travellers are more likely to go on this journey as they have saved their money and are financially equipped. The pilgrimage environment is characterized by religious congregations - with tourists engaging in communal experiences that reflect them and their faith. Therefore, the ideal experience, where tourists feel a sense of escapism from the pressures of everyday life, is a product of their ability to project, develop, and ratify their self-concept (Lochrie et al., 2019).

\section{Umrah Travel}

There are several compelling reasons to consider an Umrah pilgrimage. A major reason is that pilgrims are expected to fulfil their religious duties (Bashir et al., 2017). It is more advantageous to perform Umrah during Ramadan than at any other time of the year in terms of the extent of Allah's rewards. This belief originated from two reasons: first, there is an old hadith or saying of the Prophet Muhammad which suggests that undertaking Umrah in Ramadan ('Umrah in Ramadan equals Hajj with me') brings good fortune and rewards; and second, Muslims believe that it was during Ramadan that Muhammad first received verses from the Qur'an, marking it as an auspicious occasion (Hassan et al., 2016). Over the last years, the number of foreign pilgrims performing the Umrah has increased from 6,532.074 in 2017 to 7,457663 in 2019 (General Authority for Statistics, Saudi Arabia, 2021). Malaysia has experienced an increase in demand for Umrah among travellers (Othman et al., 2019). Prior to 2019, most international travellers were required to utilise travel agencies from their home country to make Umrah reservations due to the rules of the Saudi Ministry. However, in September 2019, the Kingdom of Saudi Arabia launched tourist e-Visas for citizens of 50 countries, including Malaysia, which contributed to an increasing demand for Umrah. This tourist visa, which is valid for up to 90 days, allows people to enter Saudi Arabia for leisure purposes. Muslims who obtain such a tourist visa can also travel to perform Umrah without the assistance of travel agents or agencies, as long it is outside the Hajj season. However, males appear to have travelled more frequently to perform Umrah, which can be explained by the views of Islamic sects on women travellers, which hold that a Muslim woman should not travel alone on a pilgrimage without being accompanied by a Mahram (husband, son or other family members like father, brother, etc) (Almuhrzi and Alsawafi, 2017).

These dynamics have been recently interrupted by the COVID-19 pandemic. Ebrahim and Memish (2020) stated that due to the COVID-19 pandemic, for the first time in eight decades, Muslim pilgrimages to holy sites in the Kingdom of Saudi Arabia (KSA) have been halted. The decision by the Kingdom of Saudi Arabia to suspend Umrah pilgrimage services comes at a high cost to the Saudi economy, including the airline, transportation, and hotel sectors, and has had a negative impact leading to employment issues and affecting the livelihood of native and immigrant workers in holy towns. According to Muneeza and Mustapha (2021), all commercial, social, and religious activities that involve actual meetings and gatherings of people have been halted, and all these activities are now being conducted online. Cancellations would have a significant impact on pilgrims from all 180+ nations, as well as the transportation and hotel industries that cater to pilgrims in the home countries. However, protecting the lives of millions of pilgrims is the main duty and honour of the Custodian of the Two Holy Cities in Islam, namely Makkah and Madinah, and is the main national priority of the KSA. Above all, a pilgrimage is a lifetime dream of Muslims, and many save their entire lives to achieve their eternal dream. According to Finatri et al. (2020), the pandemic has not dampened the enthusiasm of Umrah tourism consumers, who continue to await a statement from the Kingdom of Saudi Arabia welcoming Umrah pilgrims once again.

\section{Do It Yourself (DIY) Travel}

Do-It-Yourself (DIY) travel is related to free independent travellers (FITs) (Kireineko, 2011). However, while FITs often make little or no preparation for their trips (Tianhong, 2018), this phase of preparing a journey is important for pilgrims who will be performing Umrah. DIY is an activity in which an individual creates, changes, or produces something. Unlike any other form of 'creation', DIY projects typically require a great deal of innovation, designing, knowledge, skills, and time. With the aid of technology, such as the Internet and social media as rich sources of information, and mobile applications, DIY travellers can acquire the skills needed to learn about cultures, places, and people online without the help of professionals (Ge and Gretzel, 2018; Ryoko, 2012). Whilst other forms of independent and self-organised travels such as free independent travellers (FIT) are related to the DIY concept, DIY puts a stronger emphasis on the time and effort needed to plan and arrange a trip, along with the criteria of independence and flexibility (Tianhong, 2018). DIY was chosen as the most suitable term for this research context since Umrah requires the planning and completion of many details, which have to do with both the actual travel as well as the performance of Umrah. 
Umrah requires pilgrims to complete rituals in a specific order, including ablutions, tawaf, Sa'iy, and taqsir. Umrah pilgrims intending to make Sa'iy must make their way out of the Al-Masjid Al-Haram towards the Masaa (Ahmad et al., 2014). This proves that knowledge of the location and rituals must be well understood by the pilgrims to ensure that their worship is accepted. Traditionally, Umrah pilgrims perform their Umrah under the guidance of Mutawwif (professional guides), who are provided in travel packages. Mutawwif are important since Umrah requires the fulfilment of a series of rituals, including travelling from one location to another. DIY travellers, who have emerged as a relatively new group of travellers, can be characterised as prosumers in the sense that they choose to complete some services themselves rather than pay someone else to perform them (Wolf and McQuitty, 2011). DIY prosumers in tourism define their travel from a very individualised perspective, and they design their travel arrangements based on their personalised expectations and experience (Niezgoda, 2013). These individuals typically shun organised travel to pursue a personal and meaningful travel experience. Therefore, it can reasonably be inferred that this group has been experiencing an ongoing evolution since it first emerged due to advancements in information technology with regard to travel behaviour.

There is limited research connecting Umrah and DIY travel. Almuhrzi and Alsawafi (2017) show that over 50\% of interviewed Umrah travellers from Oman performed Umrah via self-arranged transportation, preferring to travel with family or friends. Research conducted by Lailatul and Melinda (2018) focuses on the businesses that provide services for Umrah backpackers in Indonesia. Fakhruddin and Ubaidillah (2021) conceptualise independent Umrah travellers in Indonesia as backpackers and show that they do not perform worship independently but rely on various travel parties. However, there is lack of studies exploring the experiences and motivations from the perspective of Umrah DIY travellers.

\section{Theoretical Foundation}

The study used Heinonen et al (2010) Customer-Dominant Logic (CDL) as the underpinning theoretical model to guide the study's methodological development. This theory promotes the use of customer logic mechanisms to assist businesses in developing significant positioning in the minds of their customers. Understanding the customer's logic is proposed as the foundation for the company's marketing and business logic. The customers are no longer a part of the service delivery process. Instead, they are the primary source of business growth and value creation. It is a common way of looking at what customers do with services to achieve their own goals. Value creation, according to the CDL, is based on co-production and customer cocreation. Several previous studies have echoed the importance of CDL in tourism businesses; Rihova et al. (2018) emphasised the importance of value formed when tourists cocreate with each other in tourism settings and opportunities for facilitating this process. According to Lamers et al. (2017), practise theories can be successfully applied in tourism research as an alternative to the dominant economics-driven perspectives, particularly in tourism policy. The CDL was used in a recent study by Fan et al. (2020) to investigate tourists' experiential value cocreation via online social contacts. In conjunction with this study, which focuses on UMRAH DIY travel, which has traditionally been dominated by Service-Dominant Logic (SDL) as opposed to CDL, this attempt to crisscross into travellers' perspectives is logical and justified in terms of the DIY nature as opposed to Group travelling nature.

\section{METHODOLOGY}

Due to the exploratory nature of this study, a Hermeneutic Phenomenology approach was adopted to capture and analyse the travel motivations and subjective realities of the respondents. Hermeneutics focuses on individual and group's subjective experience and is an attempt to reveal the world as experienced by the subject through their life stories. It can be carried out through empirical (collection of experiences) and reflective (analysis of their meanings) activities (Van Manen, 1990). An interview guide was used to cover a broad range of topics related to Umrah DIY. The interview guide consisted of three main sections, where open-ended interview questions were used, except for the section on the sociodemographic information (Brdesee et al., 2013). In the first section, respondents were asked to share their socio-demographic characteristics, such as gender, age, educational level, occupation, and household income. In the second section, participants were asked about their understanding of DIY travel and as well as their past experiences on travelling independently and DIY. The final section included questions about the respondents' motivations and reasons for participating in Umrah DIY travel to gain an in-depth understanding of the participants' travel motives and its underlying dimensions. The inquiry also sought to gain an understanding of the planning process as well as the participants' own thoughts and views about Umrah DIY.

Snowball sampling and convenience sampling were used to recruit the participants, who must have performed Umrah DIY at least once and had to be Malaysians. The participants were approached via Umrah DIY Facebook forum page, where members post and share their experiences of performing Umrah DIY. The potential participants were invited via a private Facebook message explaining the background and purpose of study, and there were also a few participants who helped recommend family members and friends who had experienced Umrah DIY. Although a total of 45 participants were contacted via private Facebook messages, only 20 participants were finally able to take part. The sample size was determined based on the recommendation by Creswell (1998) that the sample size for qualitative research should be in the range of 5 to 25, while Morse (1994) suggested a minimum sample size of 6 for phenomenological studies. Once the interview times were agreed upon, the interviews were conducted using online meeting tools, where MS teams and Google Hangouts Meet were used due to the ongoing Movement Control Order (MCO) as a result of the COVID-19 pandemic. Each interview lasted between 45 minutes up to 2 hours, depending on the setting and the participant's responsiveness.

The interviews were recorded during the online meeting and were subsequently transcribed between March and July 2021. The interviews were conducted in Bahasa Malaysia as all the participants were Malays, and the transcripts were later translated by the first author. To manage the interview transcripts effectively, NVivo was employed to assist in the initial 
classification and management of the data, thereby enabling a systematic and more in-depth approach to be used for the analytical process. The transcribed and translated interview data were arranged and coded according to common themes to facilitate the analysis and for comparison with the scholarly literature. For the thematic categorisation, a two-cycle coding was carried out, as proposed by Saldaña (2021). Descriptive coding was used in the first step to capture and categorise the range of views shared by the research participants. This coding method is appropriate for almost all forms of qualitative studies and includes a summary of the key concept in a passage of data in one word or a short sentence (Saldaña, 2021). Pattern coding was used in the second cycle to group the descriptive codes into a smaller number of themes (Saldaña, 2021). This coding approach was used to extract big themes from the data and to scan the data for motives or interpretations (Miles and Huberman, 2014). It allowed the researcher to build a meta-code (Saldana, 2021). The data were examined for similarities and differences across the interviews to create an understanding of the broad conditions that influenced the travellers to embark on Umrah DIY.

The trustworthiness of the data and findings were ensured by following three principles (Patricia et al., 2009): (a) attention to detail in data generation and analysis; (b) careful documentation of the thematic analysis using narrative accounts, and (c) stringent data maintenance and supervision to ensure the privacy of the study participants. In addition, this study also performed a check of the data by the respondents, where the findings were returned to the participants after the data analysis. Validation by the participants was one way to explore the credibility of the findings. The results or findings were returned to participants for them to confirm that they were consistent with their experience and accurate (Gunawan, 2015). The anonymity of the participants is a critical component of an ethical research. In presenting and discussing the findings, pseudonyms were used to report the experiences of the participants. The research flow of the study is summarised in Figure 1.

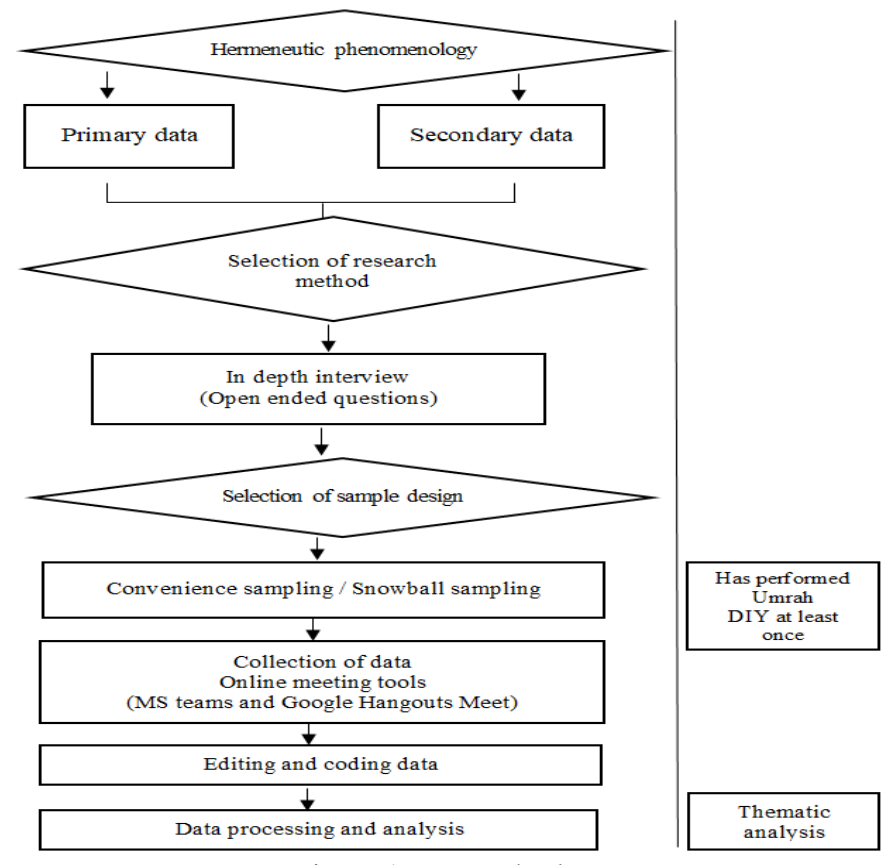

Table 1. Demographic profiles of the respondents

\begin{tabular}{|l|c|c|}
\hline \multicolumn{1}{|c|}{ Characteristics } & $\boldsymbol{n}$ & \% \\
\hline Gender & & \\
\hline Male & 7 & 35 \\
\hline Female & 13 & 65 \\
\hline Age & & \\
\hline $20-29$ & 2 & 10 \\
\hline $30-39$ & 11 & 55 \\
\hline $40-49$ & 5 & 25 \\
\hline $50-59$ & 2 & 10 \\
\hline Education & & \\
\hline High school & 1 & 5 \\
\hline Diploma & 0 & 0 \\
\hline Degree & 15 & 75 \\
\hline Master & 2 & 10 \\
\hline Ph.D & 2 & 10 \\
\hline Household Income & & \\
\hline B40 & 3 & 15 \\
\hline M40 & 10 & 50 \\
\hline T20 & 7 & 35 \\
\hline Prior Umrah experience & & \\
\hline No experience & 9 & 45 \\
\hline 1 & 6 & 30 \\
\hline$>1$ & 5 & 25 \\
\hline
\end{tabular}

\section{FINDINGS AND DISCUSSION}

\section{Respondents' Profiles}

As shown in Table 1, the ages of all the participants varied from 26 to 58 years, with $10 \%$ of them being between the ages of 20 and 29 years, 55\% between the ages of 30 and 39 years, 25\% between the ages of 40 and 49 years, and $10 \%$ between the ages of 50 and 59 years. The average age of the participants was 42 years. Thirteen of the participants were females, while the remaining seven were males. Most of the participants were holders of at least a Bachelor's degree, while $10 \%$ of the participants received their PhD from the United Kingdom, which is considered as a high level of education. In Malaysia, the income classification method is used to determine household income. Malaysians are placed into three different income classification brackets in Malaysia, namely, the B40, M40 and T20. Those in the B40 group earn between RM 2,500 and RM 4,850 per month. After the B40 comes the M40 group, which represents the middle-income earners, who account for $40 \%$ of the population of Malaysia. M40 households are defined as those earning between RM 4,850 and RM 10,959 per month. The participants' household incomes were generally in the M40 range. Representing the top $20 \%$ of income earners in Malaysia, the T20 group is categorised as those who earn from RM 10,960 to more than RM 15,039. Around $35 \%$ of the participants were from the T20 category, which covers the high-income earners. Finally, $15 \%$ of the participants belonged to the B40 category, which is the lower-income group.

According to a survey of 198 Umrah travellers conducted by Hassan et al. (2015), most of the participants in the study were earning between RM 3,500.00 and RM 4,999.99, which fell within the B40 category, while another study of 190 Umrah travellers by Hassan et al. (2016) also found that most of the participants were within the B40 category. A study among 384 Umrah package travellers by Othman et al. (2021) also found that most of the participants belonged to the B40 category, which was slightly different from the findings of this study, which identified $50 \%$ of Umrah DIY participants as being from 
the M40 category. From the interview session, 11 of the participants had performed Umrah at least once before participating in Umrah DIY; and 9 of the participants had no prior experience of performing Umrah but were very familiar with the Do It Yourself travel journey, where all of them had travelled locally and abroad independently without the aid of travel agents.

Umrah DIY Travel Motivations

The findings revealed that three important motivational factors contributed to the performance of the Umrah DIY: flexibility, budget travel, and spirituality. The sections that follow describe the findings connected with these themes and their relevance as Umrah DIY travel motivations. It was also noticed that a sense of motivation promoted the desire to return to the location and advise others.

Flexibility

One of the themes that emerged from the data analysis was flexibility. The participants expressed a sense of freedom while opting to embark on the Umrah DIY since the itinerary was tailored to their comfort and time arrangements. Flexibility is one of the primary reasons that drives independent travellers (Rosenberg, 2018). En Azli, one of the participants, had no prior experience in performing the Umrah, but he used to travel abroad when he was single and was studying medicine in Dublin, Ireland. Since he was now married, he preferred to go on DIY travels. He had never used a travel agent before, either when travelling locally or internationally. He selected Umrah DIY and emphasized that the primary reason for his choice was its flexibility. For him, the fact that he had no prior experience of Umrah was not important because he was fully aware of Umrah procedures and had been preparing for this journey since his years as an undergraduate:

"I understand the rituals in Umrah. So, when we know what to do during Umrah and how to perform it, we also know when we purchase the package, there are additional activities that aren't linked to Umrah, which inspired me to look for a DIY solution. Flexibility and freedom are the factors that lead a person to prefer to undertake Umrah on their own rather than through a package tour. It is not necessarily due to the price, as the package tours offered by travel agencies are generally fair." (Male, 40)

Encik Azli highlighted that a DIY travel allowed him to have a room to himself rather than having to share a room with other people. Having his own personal space was very important for his comfort and privacy. Apart from that, Encik Azli had no interest in other attractions or activities such as the date market or purchasing souvenirs. His self-arranged travel activities enabled him to fully concentrate on his core interest, which was spending as much time as possible at the mosque. A similar experience was shared by Dr Salma, a dentist, who had performed Umrah before with a travel agency. She stated:

"I appreciate the time flexibility since I've been on Umrah trips with travel agents, where they'll drop by to purchase dates, raisins, and scarves. I despise shopping and purchasing small items, which is why I don't like to join a travel group; they will spend a lot of time shopping, and I will usually be waiting in the bus." (Female, 36)

Dr Salma stated that during the planning stage, she would cut out everything related to shopping and fill it with ziarah, which she did throughout Madinah, visiting the Masjid al-Nabawi (Mosque of the Prophet), museums and other nearby locations. It appears that travellers choose DIY for their religious journey to focus on their main aim, which is to perform prayers and visit historical places linked with the prophet. According to a previous study by Wang et al. (2016), the main objectives of religious travellers are to strengthen their religious faith, visit the historic origins of their religion on a faith-based vacation, experience distinct cultures, and visit holy landmarks. The importance of flexibility drives believers to explore and immerse themselves in locations that enhance their appreciation of creation and faith in Allah (Nassar et al., 2015).

Deeper Spirituality

Another subject that developed was Deeper Spirituality, which is the journey of the traveller's transformation. Looking back on the interviews, spirituality was strongly connected with phrases like "life-changing" or "rewarding" experience by the participants. Most of the participants felt closer to Allah, and appreciated the travel to perform Umrah, which encouraged them to consider returning to Makkah and Madinah again, whenever the chance allowed. According to Robledo (2015), spirituality is concerned with an individual's search for meaning in life. In a broader sense, spirituality refers to the individual's experience and connection with the transcendent dimension of reality. It is an inner route that allows a person to uncover the essence of being as well as the deepest values and purposes in life. Di Giovine and Choe (2019) further explained that a pilgrimage is an extraordinary experience that leads to spiritual and personal cleansing and rebirth. Pilgrimage sites, however, continue to resound with significance for pilgrims seeking meaning, healing, consolation, and forgiveness, in accordance with the goals of spiritual travellers. The pilgrimage trip is also spiritual in nature, with the pilgrim striving for a mystical encounter or meaningful experience. This was observed when one of the participants discussed performing Umrah for the second time after missing it on the first occasion. According to Dr. Salma:

"I miss Makkah because it allows us to fully forget about work and focus on prayer. That's the distinction between here and there. Here, we will still worship, but we also have to work. I've got the opportunity to pray five times at the mosque without worry over there" (Female, 36).

This is similar to the experience of Puan Zaleha, who had the opportunity to learn how to recite the Al-Quran at Masjid Nabawi with a prominent Ustazah during Umrah DIY trip. However, as compared to Umrah travellers who travels with the help of a travel agency pre-arranged package group tours, DIY travellers feel deeper and closer to God during her Umrah DIY trip. This was possible by staying at Madinah for three weeks, which would not have been possible on a package tour, which normally lasts for 14 days for the whole trip. In describing her experience, Zaleha stated:

"Umrah is not a vacation. That is the first thing people should understand about Umrah. So, by doing it myself, I was able to fulfil my inner desires, and what I wanted from the Umrah was fulfilled, that is, I was able to study the Al-Quran with an Ustazah in Masjid Nabawi near Madinah, where I had the opportunity to study for three weeks. It is not possible for us to do this if we go under package since you will only be there for three days, but I could stay in Madinah for three weeks. I could also study near Quba's Mosque and join the Arab and Malaysian students learning the Al-Quran around 4-5 times a week." (Female, 51) 
Her experience was memorable because of DIY since she had more time to focus on her Al-Quran recital and to be in the mosque with others who were working to improve their recitation. According to Luz (2020), millions of Muslims visit a variety of sacred sites, which, as explained earlier, was a pre-Islamic custom that was eventually recognised even by religious academics. Writers referred to them as a substitute hajj, which motivated sacred travels and the obtaining of blessings from holy or pious individuals. As a result, this type of religious journey is essential, not only because it is what the majority of Muslims pursue, but also because it allows researchers to study Islam in all its complexity, as well as its local/national/regional variety and influences.

Budget Travel

All travellers have their own yearly budget that they set aside for travel. According to Sørensen (2003), this explains why independent travellers are obsessed with budgeting, often overly so, and definitely to an extent that exceeds the necessity to budget when travelling long-term. However, most of them have credit cards and are better placed financially than their appearance suggests. The capacity to travel cheaply, on the other hand, indicates road competence; it indicates that they know their way about and understand how to get products and services at inexpensive rates. Umrah DIY is seen as a more affordable pilgrimage as Umrah package tours can be quite expensive. Some of the participants compared the prices of packaged tours with the cost of a self-arranged budget travel. The experience of Puan Aishah, who was working in the oil and gas industry and had no prior experience of Umrah, showed the importance of planning with an appropriate budget:

"First and foremost, there must be a budget. Budget was in line with my expectations. Then, there's the time factor." (Female, 38)

Puan Aishah stated that her major reason for choosing Umrah DIY was to save money and time, which certainly impacted her decision to conduct Umrah. She emphasised that it was essential that she be happy and peaceful when travelling for Umrah. She did not have to adhere to the agency's schedule or wait for other members of the group to travel, which would have undoubtedly made her feel uncomfortable and been a waste of time. She disliked waiting for others, and preferred to stick to her own schedule and budget. While comparing the costs of Umrah packages and DIY travels, Puan Nadia, another first-time Umrah performer, stated that with good preparation, she was able to save on half the cost of the travel package:

"I believe that DIY is less expensive. Let's assume it's now RM 6,000 with a package, but I can get it for RM 3,000 with DIY Umrah. Apart from that, time is no longer an issue as we may go wherever we choose and eat whatever we want." (Female, 42)

By conducting a Umrah DIY, travellers can save a significant amount of money by selecting their own hotel, transportation, and activities. A similar experience was shared by En. Ali, a very experienced Umrah traveller who used to operate a travel agency before the pandemic and now runs an online business:

"The budget is critical. I once stayed at a hotel near the clock tower in Mecca. I used to bring my family, and the cost if you go with the package is RM9,000, but I was on a tight budget at the time, and I was able to stay near the clock tower for less than RM 4,500. However, if you go under the package, it is RM 9000." (Male, 34)

These illustrations show that a significant amount can be saved when travelling with Umrah DIY. According to Kotze and McKay (2020), such budget-minded travellers are constantly searching for ways to lower their travel budget. This sort of traveller will frequently use public transport, choose low-cost lodgings, and have a flexible extended trip schedule.

Factors that Support and Facilitate the Selection of Umrah DIY

In addition to the motivational factor discussed above, the findings suggested four additional factors that supported and facilitated the choice of performing the Umrah in a DIY mode: information sources, travel quality, companionship/new friendship, and familiarity. The themes below emerged throughout the Umrah DIY planning process, where participants were asked to describe why they chose Umrah DIY and to share how they planned their travel. The themes varied according to the motivating elements, in that they emphasised how essential the themes were in facilitating the success of the Umrah DIY journey. The factors helped the travellers in their planning as well as facilitated their journey. A few of the participants stated that without the facilitating factors, completing their Umrah DIY journey would have been almost impossible. According to Yoo et al. (2017), since the early days of computer networks, information technology (IT) has played an essential role in tourism. Applications, such as for flight bookings and hotel reservations, not only make it easier to have direct interactions with service providers, but also greatly facilitate and support the trip for tourists. Interactivity is a feature that allows users and administrators to conduct instant activities such as providing real-time feedback, active conversations, meetings with other people who share the same interests, and exchange information. According to Tsai (2010), self-confidence and external resources, such as available facilities, are examples of supporting conditions, which may lead independent travellers to join and advise others on the journey.

Information Sources

The availability of information regarding Umrah DIY travel is an important facilitating factor in organising the planned trips and reducing perceived and actual risks. Wang et al. (2014) mentioned that external media, such as the Internet, travel advice, and word-of-mouth, are not the sole sources of information. Internal factors such as memory and personal experience also play a role in the formation of risk perception. However, the advancement of technology has altered the behaviour of travellers, who now rely on the Internet to search for information, plan their trips, and make purchases. The development of social networking platforms like Facebook and Telegram has also influenced how individuals purchase travels (Cosma et al., 2013). Whilst online applications, social media, and the Internet play a crucial role in organising travel details and familiarising oneself with the procedures of Umrah, several of the respondents in this study engaged in additional and specialised training courses for Umrah. One of the interviewees, Dr Salma, attended an Umrah course twice during the preparation phase to ensure that she completely understood Umrah rituals. Umrah course is designed to educate future pilgrims on the rituals and religious components of the pilgrimage. The courses are usually free, and are conducted 
by Tabung Haji, which is the Malaysian haj pilgrims fund board, or by private travel agencies. Anyone who is interested may simply join to gain knowledge and prepare for the religious journey. Dr Salma's spouse, a convert, attended Umrah course four times to prepare for his first Umrah. Dr Salma also joined a Umrah DIY Telegram group, which she said was highly informative because there were many tour guides and people who had already completed Umrah DIY and were eager to share their itineraries and experiences with the group.

"Some people feel that hiring an agent for the first time is a smart decision, but I felt secure enough to follow my husband when I brought my mother because I had done it the second time and my mother had performed the Umrah several times. Besides that, I joined a Umrah DIY forum on Telegram. The group is extremely educational since there are many tour guides in there, and then there are individuals who exchange itinerary details in the group, so I can get a lot of ideas from there." (Female, 36)

Dr Salma believed that it was critical for pilgrims to attend Umrah courses provided by Tabung Haji or other relevant organisations to ensure that pilgrims are fully prepared for the trip. Since DIY travellers undertake Umrah without a package, there will be no Mutawwif (tour guide) to provide advice throughout the journey. Aside from that, she discussed her experience in searching for information via the Internet and Telegram during the preparation phase to construct her itinerary. Similarly, Puan Zaleha, whose daughter had taken over the family business after her retirement, conducted Umrah DIY with her husband in January 2020 while waiting for tips and guidance from experienced travellers. Despite having experience in performing Umrah, organising a DIY trip was difficult because she did not speak Arabic. Yet, when she learned that it was possible to conduct Umrah independently, she decided to grab this opportunity. She consulted other Umrah travellers and gathered travel information online to prepare herself for the journey.

"When I heard the Arabs are allowing us to perform the Umrah DIY, I felt like going as both my husband and I are retired, and we have let the children take over the business. I didn't feel like rushing as there was a need to gather information from other travellers. I followed a few group pages on Umrah DIY and asked for tips and guidance from experienced Umrah DIY travellers. After 3 months of gathering information and reading about other travellers' experiences online, we are confident." (Female, 51)

The findings showed that information on Umrah DIY was freely available online, especially through social media groups such as Facebook as well as Telegram groups, which were used to exchange experiences and advice, thereby assisting DIY travellers to overcome their fear of performing Umrah independently. This was consistent with Marder et al. (2021), who stated that travellers will have quick textual and visual access to information online, and will be able to refer to photos posted by destination managers and other travellers. Tourists or user-generated material may be available on a wide range of social media platforms, including both travel specific (e.g., TripAdvisor, Yelp) and general sites (e.g., Facebook, Instagram, Telegram).

Travel Quality

There is a link between the source of information and the quality of travel. Essentially, travel quality includes adequate sanitation and hygiene, transportation quality, retail centres, lodging, excellent restaurants, and recreational activities. According to Boz and Karakas (2017), the effect of the destination image on travel quality falls within the scope of 'good reputation.' As a result, it is reasonable to conclude that a good reputation for travel quality is beneficial in gaining the perception of quality from travellers, particularly when it comes to independent travel. Dr Salma was pleased with the services that were available at the hotel since they offered playground services, where she could leave her children while she went for prayers:

"There are several hotels close to the Haram Mosque. They provide children's playground services. We can take the playground package if we only come along with our spouse and no one else can assist in taking care of the youngsters. It is not costly, only RM 40 per hour". (Female, 36)

With such services being provided by the hotel, travellers are not only able to focus on their prayers, but they also have peace of mind knowing that someone is caring for their children. In addition, another tourist, Puan Aimi, who works as a systems engineer, stated that the amenities provided in Saudi Arabia made it possible for her to perform Umrah on her own. According to Doheim et al. (2019), Makkah has evolved into a digital city with the development of its infrastructure to provide services to its citizens and travellers (e.g., health, real estate, safety and security), with advanced technology for more efficient performance, as well as having an environmental city with technology.

"The facilities are excellent. Everything is simple in terms of arranging hotels and transportation. That is why I want to do my own Umrah." (Female, 35)

She emphasised that it was not a problem to decide on Umrah DIY because Saudi Arabia is a well-developed country, coupled with great facilities, and it was her second time performing the Umrah. She was confident about embarking on Umrah DIY because all the information on hotels and transportation could be found online. She was able to compare hotel prices via Agoda, which aided her in her decision. Transportation was easily accessible, thanks to Uber, which she had downloaded before arriving in Saudi Arabia.

Companionship / New Friendship

Social media has created a new way for people to engage with each other, and friendships have evolved as a result. In past generations, a friend was someone with whom one could naturally connect with in everyday situations, whereas friends made through the Internet may be somewhat unknown. Shuo, Ryan and Liu (2009) noted that one of the factors that inspire pilgrims is social contact, which is centred on religious events, social engagements with friends and other religious believers, and the enjoyment of the journey and the satisfaction of intellectual curiosity. This could be observed in Umrah DIY journey, where most of the participants met new friends through the DIY Umrah Facebook forum and other online media who shared the same goal, which was to complete Umrah without the assistance of an agency. Some of them even planned their itinerary together, while others discussed the trip online. Puan Laila, a stay-at- 
home spouse, participated in Umrah DIY with her daughter. As she was afraid of travelling, she decided to look for another person on Umrah DIY Forum who would be going on the same day as her. Coincidentally, another woman was planning to complete her Umrah alone. As a result, they booked the same hotel and flight.

"I first intended to take my daughter. People said it was risky for both of us to go alone. So, I looked for someone else to join us as well. Then, it just so happened that a woman also wanted to do the DIY and agreed to join me. So, we boarded the plane and booked a room together, but we didn't perform the Umrah together. Both of us followed our own schedule in terms of the Umrah but did make time to grab lunch or dinner together." (Female, 42)

The constraints with regard to pilgrimage travel include poor health, and lack of time due to work commitments. Shuo, Ryan and Liu (2009) also suggested that potential tourists who are widows or single sometimes do not travel since they do not have a travelling partner. Another factor that interferes and makes it more difficult for them to travel is that they need to care for their own elderly parents while also planning to meet their own needs. This limits their travel time and may cause them to reconsider spending money on a trip. In this context, one of the recognisable constraints to Umrah DIY travel is the lack of a companion. For Puan Laila, having companions, including her daughter and new friend, Puan Habsah, increased her confidence in the journey. One of the respondents, En Hadi, a schoolteacher, emphasised that to complete Umrah DIY, it was necessary for him to be more sociable as there was no one to lead them. He mentioned that two ways he used to make acquaintances and seek information to simplify his Umrah travel were to approach strangers for information and meet locals for guidance.

"The first day I entered Raudah, I prayed, 'Oh God, help me on my journey and let me visit the prophet's sites here.' And then, in Raudah, magically, I met a US citizen, Muhamad, who resides in Jeddah. We talked and he asked whether I would like to visit the area as he noticed that I was traveling without an agent. Then, he informed me about his friend, who could show me around at a very cheap price." (Male, 32)

En Hadi was happy to meet Muhamad, who was willing to refer him to a local friend. He learned a lot about the history and places that most travellers had yet to see and that only locals would know about.

Familiarity

Individuals with more travel experience are more inclined to purchase trips online (Amaro and Duarte, 2013). The frequency of travel has a favourable impact on online searches, online purchases, and customised orientations. There was evidence of this as one of the interviewees, Puan Aimi, was highly experienced with DIY travel, having visited Korea, Maldives, Indonesia, and Thailand without the need of an agent. Although she did not purchase a tour package for her trip to Indonesia, she hired a driver to take her around the city. Furthermore, this was her second Umrah, having previously completed her first Umrah with a package tour. As a result of her familiarity with the rituals and locations, she was confident in doing Umrah DIY.

"That depends. Some are do-it-yourself, while others are pre-packaged. For example, I've visited Korea, Maldives, Indonesia, and Thailand with DIY, but in Bandung, I occasionally hire a driver." (Female, 35)

Although she arranged some trips on her own, but occasionally she would hire drivers or purchase pre-packaged trips to facilitate her journey. A similar experience was shared by another traveller, Puan Zaleha, who was familiar with the DIY concept because, as a businesswoman, she would have to go to countries like Indonesia and Thailand to purchase goods. As for the Umrah, she had performed it 5 times with a travel agent.

"Because of business, I've always travelled overseas from a young age, even as far as Indonesia. It's very common for me to go to buy goods to trade, then, I will travel to Thailand as well. For the Umrah, I have gone there about five times." (Female, 51).

Performing Umrah five times would undoubtedly have allowed Puan Zaleha to become familiar with the rituals and locations in Makkah and Madinah. Choosing to do the Umrah DIY will not be a problem if you are well-versed with the area. Similarly, En Aiman, who was a teacher at a religious school, had performed Umrah before with an agent and enjoyed travelling either solo or with friends to other countries. He decided to perform his second Umrah independently by DIY as he was familiar with the rituals and preferred to travel solo.

"I would usually travel with friends or solo. My solo trip to London was a DIY and I have performed the Umrah before with my family through a package." (Male, 26)

En Aiman appeared to be a person who enjoyed travelling, and despite being single, he had visited a few countries on his own. As a religious teacher, he was also knowledgeable about the rituals, and understood Arabic, which contributed to his confidence in doing Umrah DIY.

Table 2. Importance rankings of Umrah Do It Yourself selection

\begin{tabular}{|c|c|c|}
\hline Rank & Umrah Do It Yourself selection & Coding references \\
\hline 1 & Flexibility & 41 \\
\hline 2 & Information sources & 30 \\
\hline 3 & Familiarity & 22 \\
\hline 4 & Travel quality & 21 \\
\hline 5 & Companion / New friendship & 21 \\
\hline 6 & Budget travel & 18 \\
\hline
\end{tabular}

As indicated in Table 2, the rankings were identified

based on the coding references, which were essentially the textual identifiers linked to the theme. "Deeper Spirituality" and "budget travel" had the fewest coding references (18), followed by "companion/new friendship" and "travel quality" (21). Following that, the third most important reason for Umrah DIY was "familiarity", with 22 coding references, followed by "information sources" (30), while the most important reason was "flexibility", with the most coding references (41).

\section{CONCLUSION}

The aim of this study was to explore the complex motivations and dimensions of Umrah Do-It-Yourself (DIY) travel and the factors that facilitate the decision-making for a more independent form of pilgrimage. With the revision of the EUmrah Visa policy by the government of Saudi Arabia in 2019, there has been a growing trend towards DIY by international pilgrims who perform their Umrah independently instead of going through travel agencies. Flexibility, 
budget travel and deeper spirituality were the themes that emerged to explain why Umrah DIY opt to plan and manage the most important travel in their lifetime by themselves. Findings further showed that internet sources including usergenerated content on social media platforms were the main factor that supported this shift from a pre-packed Umrah tour to a Umrah DIY. According to Othman et al. (2021), the advancement of the Internet allows online communities with the same interests to search, connect, and share their travel experiences via different social media platforms. Previous studies have shown that most travellers would refer to past tourist reviews shared on online platforms before deciding on their trips (Collie, 2014; Gretzel and Yoo, 2008; Vermeulen and Seegers, 2009; Ye et al., 2009). This was also observed in the current study as Umrah DIY travellers used the platforms on social media to consult and learn from the experiences of other DIYers on how to plan and support their process of decision making in planning for the Umrah visit. This was especially apparent among those experienced travellers who had visited the holy sites before or experienced DIY travellers as they looked for a more distinctive and immersive travel experiences.

\section{Theoretical Implications}

Theoretically, this research contributes to the intersecting terrain of religious and independent travel. Previous studies on Muslim pilgrimage focused on Hajj and existing research on Umrah tended to concentrate on identifying several sets of practices for service quality and the criteria for selecting an Umrah travel agency (Bashir et al., 2017; Muhammad and Artanti, 2016; Muslim et al., 2020). The only studies on Umrah DIY were found to have focused on the feasibility of Umrah backpackers among young Indonesian travellers (Lailatul and Melinda, 2018; Fakhruddin and Ubaidillah, 2021), and Hajj backpackers regarding the possibilities and obstacles of religious travellers (Kusumaningtyas, 2019). Findings highlight budget conscious travellers and the need for flexibility as it has also been documented for other forms of independent travel such as backpacking. However, Umrah DIY travellers look for a deeper spiritual and religious experience and at the same time appreciate the forming of new social relationships during their individual journeys. As tourists seek ways to maximise their experiences, this study may help in the creation of DIY travel options for Umrah pilgrims. Findings highlight a strong desire for flexibility and independence, as most of the participants were not in favour of following a fixed itinerary provided by the travel agency or travelling in groups. Some respondents are not interested in sightseeing, shopping, or visiting museums, which will be provided in Umrah package travel by the travel agency. The ability to be flexible has allowed Umrah DIY traveller to meet new people while also focusing on the core objective of Umrah, which is performing the rituals. When conducting Umrah DIY, there is a deeper contact with Allah because the attention has shifted primarily to prayers and the travellers would rely solely on Allah to ease the journey because there is no agency to guide or assist.

As this study was exploratory in nature, it provides a useful direction for future research to investigate the theoretical development in customer dominant logic (Heinonen et al., 2010). From a theoretical marketing perspective, the study suggests that the ultimate goal of marketing should be the customer experience and the resulting value-in-use for customers in their specific context, rather than the service. As a result, the central question is how Umrah operators, the public sector such as the respective ministries, and promotional boards can support ongoing activity and experience structures for Umrah DIY travellers. Besides, in line with developing a conceptual model based on customer dominant logic, the outcome of this study suggests that perceived flexibility and sense of independence are important variables in customizing Yi and Gong's (2013) measurement scale towards customer value co-creation behaviour in the context of Umrah DIY intention.

\section{Practical Implications}

The findings of the study provide valuable information to local governments, managers of the pilgrims' sites and future Umrah DIY travellers. The findings showed that the combination of advanced technology and shift in the visa regulations have created a new wave of Umrah DIY travellers who are increasingly accustomed to using social media and other internet sources to plan their spiritual tours. As such, the Saudi Arabian Government should play the leading role in developing successful marketing packages to promote the Umrah E-Visa to realise the Vision 2030 blueprint to tap on tourist markets beyond religious pilgrims as part of an economic revolution plan especially after tourism industry is badly hits by Covid-19 pandemic. Umrah DIY travellers with positive travel experiences in the country can also promote the image of the destination beyond the religious image and may be a source of return travellers. In addition, the findings can support managers of pilgrimage sites, especially those providing hospitality facilities such as hotels and transportation to understand the preferences and expectation of this new group of Umrah travellers. The managers can use the findings of this paper to repackage their products to cater to their demand. Lastly, as this paper also sought to explore the factors that support and facilitate the decision to choose Umrah DIY, this helps to provide some useful guidance to prepare the future Umrah travellers in planning for their spiritual journey using the DIY approach.

\section{Limitations and Future Research}

This study was not free of limitations. The first limitation of this study was related to the recruitment of a sufficient sample that fitted the criteria of performing Umrah travels using the DIY approach at least once. As the introduction of the e-Umrah visa was only initiated in 2019, and was suspended in 2020 due to the outbreak of Covid-19, few Malaysians are aware of it and have undertaken Umrah journeys using the DIY approach. Secondly, due to continuing concerns about Covid-19, the interviews were mainly conducted online via the Zoom platform. Even though the online platform was a safer approach for conducting the interviews during the pandemic, there were technical issues, such as poor connectivity during the interview, which complicated the interview process as sometimes there were delays in the transmission and the researchers were unable to hear or communicate with the respondents efficiently and vice versa. In addition, some respondents were not comfortable about speaking in front of the screen, while some of them turned down the invitation. On comparing the benefits as well as the 
drawbacks of online interviews, face-to-face interviews are still regarded as a better approach for future researchers to conduct the interviews in the context of Malaysia. In addition, as this was one of the first studies to explore the phenomenon of Umrah DIY, besides looking into the motivations as well as the factors that facilitate the selection of the DIY approach, perhaps future researchers could extend the study investigating the barriers and challenges that are encountered by Umrah DIY when planning and performing Umrah, and the sociodemographic factors that might influence the motivation to travel using the DIY approach, for example, the demographic factors, such as age, gender, and socioeconomic status.

\section{REFERENCES}

Ahmad, M.F., Arif, M.S.M., Zakuan, N., Rahman, S.S.S.A., Abdullah, T.A.R., \& Fadzil, N. (2014). The Effect of Demographics on Customer Satisfaction amongst Malaysia Hajj Pilgrims: Survey Result. Applied Mechanics and Materials, 660, $1000-1004$.

Almuhrzi, H.M., \& Alsawafi, A.M. (2017). Muslim perspectives on spiritual and religious travel beyond Hajj: Toward understanding motivations for Umrah travel in Oman. Tourism Management Perspectives, 24, 235-242. https://doi.org/10.1016/j.tmp.2017.07.016

Amaro, S., \& Duarte, P. (2013). Online travel purchasing: A literature review. Journal of Travel and Tourism Marketing, 30(8), 755785. https://doi.org/10.1080/10548408.2013.835227

Bashir, H., Beigh, R.A., Rumysa, B.S., \& Bazaz, A.Y. (2017). Experience of Umrah Trip to Saudi Arabia from Kashmir India: Model Study on Management and Facilities to Pilgrims by Custodian of Holy Mosques Kingdom of Saudi Arabia. Journal of Tourism and Hospitality, 6(328), 2167-0269. https://doi.org/10.4172/2167-0269.1000328

Battour, M., Ismail, M.N., \& Battor, M. (2011). The impact of destination attributes on Muslim tourist's choice. International Journal of tourism research, 13(6), 527-540.

Boz, M., \& Karakas, E. (2017). The Effect of Information Sources ,Travel Motivation and the Effect of Information Sources , Travel Motivation and. September 2016. International Journal of Arts and Commerce, 5(6), 1-16. https://ijac.org.uk/images/ frontImages/gallery/Vol._5_No._6/1._1-16.pdf.

Brdesee, H., Corbitt, B., \& Pittayachawan, S. (2013). Barriers and motivations affecting information systems usage by Hajj-Umrah religious tourism operators in Saudi Arabia. Australasian Journal of Information Systems, 18(1), 5-23. https://doi.org/10.3127/ajis.v18i1.809

Cosma, S., Bota, M., Tutunea, M., Andi, A., Kim, M.J., Chung, N., Lee, C.K., Razak, N.S.A., Marimuthu, M., Omar, A., Mamat, M., Amaro, S., Duarte, P., Davis, F.D., \& Of, B. (2013). Factors that Influence the Purchase of Travel Online - A Holistic Approach. MIS Quarterly, 1153-1157. https://www.jstor.org/stable/249008?origin=crossref\%0Ahttp://dx.doi.org/10.1016/j.sbspro.2014.04.067\%0 Ahttp://dx.doi.org/10.1016/S2212-5671(12)00245-6

Collie, M. (2014). Internet leads travel. Geton. com, accessed on 30 April 2020. http://www.geton.com/blog/geton/internetleads-travel

Creswell, J.A. (1998). Five qualitative traditions of inquiry. Qualitative inquiry and research design, Choosing among five traditions, 47-72.

Cuesta-Valiño, P., Bolifa, F., \& Núñez-Barriopedro, E. (2020). Sustainable, smart and Muslim-friendly tourist destinations. Sustainability, 12(5), 1778.

Di Giovine, M.A., \& Choe, J. (2019). Geographies of religion and spirituality: pilgrimage beyond the 'officially' sacred. Tourism Geographies, 21(3), 361-383. https://doi.org/10.1080/14616688.2019.1625072

Doheim, R.M., Farag, A.A., \& Badawi, S. (2019). Smart city vision and practices across the Kingdom of Saudi Arabia-a review. Smart cities: Issues and challenges, 309-332. https://doi.org/10.1016/B978-0-12-816639-0.00017-X

Ebrahim, S.H., \& Memish, Z.A. (2020). Saudi Arabia's drastic measures to curb the COVID-19 outbreak: Temporary suspension of the Umrah pilgrimage. Journal of Travel Medicine, 27(3), 1-2. https://doi.org/10.1093/jtm/taaa029

Eid, R., \& El-Gohary, H. (2015). The role of Islamic religiosity on the relationship between perceived value and tourist satisfaction. Tourism management, 46, 477-488.

Fan, D.X., Hsu, C.H., \& Lin, B. (2020). Tourists' experiential value co-creation through online social contacts: Customer-dominant logic perspective. Journal of Business Research, 108, 163-173.

Finatri, I., Pono, M., \& Jusni, J. (2020). Effect Covid-19: Loyalty of Prospective Umrah Pilgrims to Umrah and Hajj Travel Companies. Hasanuddin Journal of Business Strategy, 2(3), 31-37. https://doi.org/10.26487/hjbs.v2i3.353

Ge, J., \& Gretzel, U. (2018). A taxonomy of value co-creation on Weibo - a communication perspective. International Journal of Contemporary Hospitality Management, 30(4), 2075-2092.

Gretzel, U., \& Yoo, K.H. (2008). Use and impact of online travel reviews. Information and communication technologies in tourism $2008,35-46$.

Gunawan, J. (2015). Ensuring Trustworthiness in Qualitative Research. Belitung Nursing Journal, 1(1), 10-11. https://doi.org/10.33546/bnj.4

Gornall, J. (2020). Saudi Arabia taking all measures to keep Hajj safe. Arab News. https://www.arabnews.com/node/ 1710066/saudi-arabia

Hassan, S.H., Maghsoudi, A., \& Nasir, N.I.M. (2016). A conceptual model of perceived value and consumer satisfaction: a survey of Muslim travellers' loyalty on Umrah tour packages. International Journal of Islamic Marketing and Branding, 1(3), 215. https://doi.org/10.1504/ijimb.2016.075851

Hassan, S.H., Mohamed Zainal, S.R., \& Mohamed, O. (2015). Determinants of Destination Knowledge Acquisition in Religious Tourism: Perspective of Umrah Travelers. International Journal of Marketing Studies, 7(3), 84-95. https://doi.org/10.5539/ijms.v7n3p84

Haq, F., \& Wong, H.Y. (2010). Is spiritual tourism a new strategy for marketing Islam? Journal of Islamic Marketing, 1 (2), 136-148.

Haq, F., \& Jackson, J. (2009). Spiritual journey to Hajj: Australian and Pakistani experience and expectations. Journal of Management, Spirituality and Religion, 6(2), 141-156.

Heidari, A., Hamid, R.Y., Fatemeh, S., \& Mohammad, R.J. (2018). The perspective of religious and spiritual tourism research: a systematic mapping study. Journal of Islamic Marketing, 9(4), 747-798.

Heinonen, K., Strandvik, T., Mickelsson, K. J., Edvardsson, B., Sundström, E., \& Andersson, P. (2010). A customer-dominant logic of service. Journal of Service management. 21(4), 531-548.

Irimias, A., Mitev, A., \& Michalko, G. (2016). Demographic characteristics influencing religious tourism behaviour: evidence from a central-Eastern-European country. International Journal of Religious Tourism and Pilgrimage, 4(4), 19-32.

Kireienko, K.V. (2011). English for Tourism. http://dspace.luguniv.edu.ua/jspui/bitstream/123456789/1232/1/Kirienko.pdf

Kim, B., Kim, S., \& King, B. (2020). Religious tourism studies: evolution, progress, and future prospects. Tourism Recreation Research, 45(2), 185-203. https://doi.org/10.1080/02508281.2019.1664084

Kotze, N., \& McKay, T. (2020). South Africans Walking the Camino: Pilgrimage or Adventure. African Journal of Hospitality, Tourism and Leisure, 9(6), 997-1011. https://doi.org/10.46222/ajhtl.19770720-64

Kusumaningtyas, M. (2019). Haji backpacker: Peluang Dan Tantangan. Malia, Jurnal Ekonomi Islam, 11(1), 39-50.

Lailatul, A., \& Melinda, T. (2018). Feasibility Study Of Religion Tourism Business For The Young People. Trikonomika, 17(1), 20. https://doi.org/10.23969/trikonomika.v17i1.637

Lamers, M., Van der Duim, R., \& Spaargaren, G. (2017). The relevance of practice theories for tourism research. Annals of Tourism research, 62, $54-63$.

Liu, Y.C., Li, I.J., Yen, S.Y., \& Sher, P.J. (2018). What Makes Muslim Friendly Tourism? An Empirical Study on Destination Image, Tourist Attitude and Travel Intention. Advances in Management \& Applied Economics, 8(5), $27-43$. 
Lochrie, S., Baxter, I.W., Collinson, E., Curran, R., Gannon, M.J., Taheri, B., \& Yalinay, O. (2019). Self-expression and play: can religious tourism be hedonistic? Tourism Recreation Research, 44(1), 2-16. https://doi.org/10.1080/02508281.2018.1545825

Luz, N. (2020). Pilgrimage and religious tourism in Islam. Annals of Tourism Research, 82,102915. https://doi.org/10.1016/j.annals.2020.102915

Fakhruddin, M., \& Ubaidillah, A. (2021). Phenomenon of Umrah Backpacker Implementation: Case Studies in Bekasi and Bogor. In: ISRL 2020, 2-5 November 2020, Bogor, Indonesia. https://doi.org/10.4108/eai.2-11-2020.2305065

Marder, B., Erz, A., Angell, R., \& Plangger, K. (2021). The Role of Photograph Aesthetics on Online Review Sites: Effects of Management- versus Traveler-Generated Photos on Tourists' Decision Making. Journal of Travel Research, 60(1), 31-46. https://doi.org/10.1177/0047287519895125

Muhammad, \& Artanti, Y. (2016). The Impact Of Experiential Marketing On Word Of Mouth ( WOM ) With Customer Satisfaction As The Intervening Variable Pengaruh Experiental Marketing Terhadap Word Of Mouth ( WOM ) Dengan Kepuasan Pelanggan Sebagai Variabel Intervening. Jurnal Dinamika Manajemen, 7 (2) 2016, 182-190, 7(36), 182-190.

Muneeza, A., \& Mustapha, Z. (2021). COVID-19: it's impact in Hajj and Umrah and a future direction. Journal of Islamic Accounting and Business Research, 12(5), 661-679. https://doi.org/10.1108/JIABR-02-2021-0062

Muslim, A., Harun, A., Ismael, D., \& Othman, B. (2020). Social media experience, attitude and behavioral intention towards umrah package among generation X and Y. Management Science Letters, 10(1), 1-12. https://doi.org/10.5267/j.msl.2019.8.020

Miles, M.B., Huberman, A.M., \& Saldana, J. (2014). Qualitative data analysis: A methods sourcebook. Thousand Oaks, CA: Sage.

Morse, J.M. (1994). Designing funded qualitative research. Handbook of qualitative research, 220-235, Sage Publications, Inc.

Nassar, M.A., Mostafa, M.M., \& Reisinger, Y. (2015). Factors influencing travel to Islamic destinations: An empirical analysis of Kuwaiti nationals. International Journal of Culture, Tourism, and Hospitality Research, 9(1), 36-53. https://doi.org/10.1108/IJCTHR-10-2014-0088

Niezgoda, A. (2013). Prosumers in the tourism market: the characteristics and determinants of their behaviour. Poznan University of Economics Review, 13(4), 130-140.

Nurul'Ain, M., \& Khairul Faezi, M.S. (2019). Penipuan pakej Umrah: Penyelesaian daripada perspektif peniaga Islam. Global Journal Al-Thaqafah, GJAT, Special Issues, 145.

Othman, B.A., Harun, A., De Almeida, N.M., \& Sadq, Z.M. (2021). The effects on customer satisfaction and customer loyalty by integrating marketing communication and after sale service into the traditional marketing mix model of Umrah travel services in Malaysia. Journal of Islamic Marketing, 12(2), 363-388. https://doi.org/10.1108/JIMA-09-2019-0198

Patricia Benner, R.N., Christine Tanner, R.N., \& Catherine Chesla, R.N. (2009). Expertise in nursing practice: Caring, clinical judgment, and ethics. Springer Publishing Company, Eds.

Pintér, A.R. (2014). Religious tourism in Mecca [Master's thesis Budapest Business School]. http://dolgozattar.repozitorium.unibge.hu/1065/1/Szakdolgozat\%20Pint\%C3\%A9r\%20Anna\%20Rita.pdf.

Rasul, T. (2019). The trends, opportunities and challenges of halal tourism: A systematic literature review. Tourism Recreation Research, 44(4), 434-450.

Rihova, I., Buhalis, D., Gouthro, M.B., \& Moital, M. (2018). Customer-to-customer co-creation practices in tourism: Lessons from customer-dominant logic. Tourism Management, 67, 362-375, search, 44(4), 434-450.

Raj, R., \& Bozonelos, D. (2015). Pilgrimage experience and consumption of travel to the city of Makkah for Hajj ritual. International Journal of Religious Tourism and Pilgrimage, 3(1), 38-45.

Robledo, M.A. (2015). Tourism Research Frontiers : Beyond the Boundaries of Knowledge Tourism of Spiritual Growth as a Voyage of Discovery Article information: Tourism Social Science Series, 20, 71-86. https://doi.org/10.1108/S1571-504320150000020009

Rosenberg, H. (2018). The "flashpacker" and the "unplugger": Cell phone (dis)connection and the backpacking experience. Mobile Media and Communication, 7(1), 111-130. https://doi.org/10.1177/2050157918777778

Ryoko, N. (2012). DIY Tourism as Learning Culture and Accessing Authenticity (Doctoral dissertation, UCLA).

Saldaña, J. (2021). The coding manual for qualitative researchers. sage.

Shuo, Y.S., Ryan, C., \& Liu, G. (2009). Taoism, temples and tourists: The case of Mazu pilgrimage tourism. Tourism Management, 30(4), 581-588. https://doi.org/10.1016/j.tourman.2008.08.008

Shafaei, F. (2017). The relationship between involvement with travelling to Islamic destinations and Islamic brand equity: A case of Muslim tourists in Malaysia. Asia Pacific Journal of Tourism Research, 22(3), 255-271.

Sørensen, A., 2003. Backpacker Ethnography. Annals of Tourism Research. 30(4), 847-867.

Stephenson, M.L. (2014). Deciphering 'Islamic hospitality': Developments, challenges and opportunities. Tourism Management, 40, $155-164$.

Timothy, D., \& Olsen, D. (2006). Tourism, religion and spiritual journeys. London: Routledge, Eds.

Tianhong, Z. (2018). A study of Chinese Free Independent travellers' motivations and their preferred accommodation types in New Zealand. Auckland University of Technology.

Tsai, C. (2010). Applying the theory of planned behavior to explore the independent travelers behavior. African Journal of Business Management, 4(2), 221-234.

Van Manen, M. (1990). Beyond assumptions: Shifting the limits of action research. Theory into practice, 29(3), 152-157.

Vermeulen, I.E., \& Seegers, D. (2009). Tried and tested: The impact of online hotel reviews on consumer consideration. Tourism management, 30(1), 123-127.

Wang, W., Chen, J.S., \& Huang, K. (2016). Religious Tourist Motivation in Buddhist Mountain: The Case from China. Asia Pacific Journal of Tourism Research, 21(1), 57-72. https://doi.org/10.1080/10941665.2015.1016443

Wang, Z., Yang, Z., Wall, G., Xu, X., Han, F., Du, X., \& Liu, Q. (2014). Is it better for a tourist destination to be a world heritage site? visitors' perspectives on the inscription of kanas on the world heritage list in China. Journal for Nature Conservation, 23 , $19-26$. https://doi.org/10.1016/j.jnc.2014.11.001

Wolf, M., \& McQuitty, S. (2011). Understanding the do-it-yourself consumer: DIY motivations and outcomes. AMS Review, 1(3-4), 154-170. https://doi.org/10.1007/s13162-011-0021-2

Wu, C.H.J., \& Mursid, A. (2020). Loyalty motivations for religious tourism: Indonesian Muslim travelers umrah participating in umrah pilgrimage to Mecca, Saudi Arabia. Tourism Review, 75(2), 466-478. https://doi.org/10.1108/TR-11-2018-0155

Ye, Q., Law, R., \& Gu, B. (2009). The impact of online user reviews on hotel room sales. International Journal of Hospitality Management, 28(1), 180-182.

Yi, Y., \& Gong, T. (2013). Customer value co-creation behavior: Scale development and validation. Journal of Business research, 66(9), $1279-1284$.

Yoo, C.W., Goo, J., Huang, C.D., Nam, K., \& Woo, M. (2017). Improving travel decision support satisfaction with smart tourism technologies: A framework of tourist elaboration likelihood and self-efficacy. Technological Forecasting and Social Change, 123, 330-341. https://doi.org/10.1016/j.techfore.2016.10.071

*** General Authority for Statistics (2021). Latest Statistical Releases | General Authority for Statistics (stats.gov.sa)

*** Pew Research Centre. (2021). Muslims are a growing presence in U.S., but still face negative views from the public. https://www.pewresearch.org/fact-tank/2021/09/01/muslims-are-a-growing-presence-in-u-s-but-still-face-negative-views-from-the-public/ 